\title{
Pengaruh Pemberian Daun Ubi Jalar Ungu (Ipomoea batatas Lam) terhadap Kadar TNF-A, II-6 dan Nf-Kb pada Tikus yang Dipapar Asap Rokok
}

\section{Effect of Purple Sweet Potato Leaf (Ipomoea batatas Lam) Administration on TNF-A, II-6 dan Nf- $K b$ Levels on Smoke Exposed Rats}

\author{
Inggita Kusumastuty ${ }^{1}$, Prasetyo Adi', Leny Budhi $\mathrm{H}^{1}$, Fajar Ari $\mathrm{N}^{1}$ \\ ${ }^{1}$ Laboratorium IImu Gizi Fakultas Kedokteran Universitas Brawijaya Malang \\ ${ }^{2}$ Laboratorium Biokimia-Biomolekuler Fakultas Kedokteran Universitas Brawijaya Malang
}

\begin{abstract}
ABSTRAK
Peningkatan stres oksidatif dapat memicu inflamasi yang berperan dalam perkembangan Chronic Obstructive Pulmonary Disease (COPD). Daun ubijalarungu/Purple Sweet Potato Leaves (PSPL) memiliki kandungan polifenol yang tinggi yaitu sebesar 1805 mg GEA (gallic acid eguivalent) dalam 100 gram tepung PSPL. Tujuan penelitian ini untuk membuktikan pengaruh pemberian daun ketela ungu terhadap perbaikan marker inflamasi yaitu TNF- $\alpha$, IL-6, dan NF-kB pada tikus yang dipapar asap rokok. Hewan coba dibagi menjadi 5 kelompok perlakuan yaitu tidak dipapar asap rokok, dipapar asap rokok, dan dipapar asap rokok dengan penambahan PSPL sebesar 0,07g, 0,14g, dan 0,28g selama 30 hari dalam bentuk tepung. Pengukuran TNF- $\alpha$, IL-6, dan NF-KB dilakukan dengan menggunakan metode ELISA. Hasil penelitian menunjukkan bahwa pada tikus yang dipapar asap rokok dan ditambahkan tepung PSPL sebesar 0,14 g memiliki kadar TNF- $\alpha$, IL-6, dan NF-kB paling rendah jika dibandingkan dengan kelompok yang terpapar asap rokok dengan dua dosis PSPL lainnya.
\end{abstract}

Kata Kunci: Daun ubi jalar ungu, IL-6, NF-KB, paparan asap rokok, TNF- $\alpha$

\begin{abstract}
Increasing oxidative stress can trigger inflammation which plays an important role in the development of Chronic Obstructive Pulmonary Disease (COPD). Purple Sweet Potato Leaves (PSPL) has high polyphenol content which is $1805 \mathrm{mg}$ GEA (gallic acid eguivalent) in 100grams of PSPL flour. This study aims to prove that PSPL can repair the inflammatory marker (TNF- $\alpha, I L-6$, and NF-KB) in rats exposed to cigarette smoke. Experimental animals were divided into 5 treatment groups, i.e. without cigarette smoke exposure, with cigarette smoke exposure, and cigarette smoke exposure with 3 different dosages of PSPL flour, consecutively $0,07 \mathrm{~g}, 0,14 \mathrm{~g}$, and $0,28 \mathrm{~g}$ for 30 days. The levels of TNF- $\alpha, \mathrm{LL}-6$, and NF-KB were measured using ELISA. The results showed that the levels of TNF- $\alpha, I L-6$, and NF-KB in rats exposed cigarette smoke and $0,14 \mathrm{~g}$ PSPL flour is the lowest compared to two other groups that exposed to cigarete smoke with two other dossages of PSPL.
\end{abstract}

Keywords: Cigarette smoke exposure, IL-6, NF-KB, Purple Sweet Potato Leaves, TNF- $\alpha$

Jurnal Kedokteran Brawijaya, Vol. 28, No. 3, Februari 2015; Korespondensi: Inggita Kusumastuty. Laboratorium IImu Gizi Fakultas Kedokteran Universitas Brawijaya Malang, Jl. Veteran Malang Tel. (0341)569117Email: inggita.kusuma@gmail.com 


\section{PENDAHULUAN}

Merokok dianggap sebagai penyebab utama beberapa penyakit saluran pernafasan, terutama Chronic Obstructive Pulmonary Diseases (COPD) (1). WHO memperkirakan di negara-negara dengan pendapatan tinggi, 73\% mortalitas COPD berkaitan dengan merokok. Pada negara-negara dengan pendapatan menengah kebawah sebanyak $40 \%$ mortalitas diakibatkan oleh merokok (2). Asap rokok mengandung lebih dari 4700 senyawa kimia dan oksidan yang dapat memicu stress oksidatif, dan tingginya stress oksidatif dapat memicu pelepasan sitokin pro inflamasi yang berperan dalam perkembangan COPD. Hasil penelitian sebelumnya, menunjukkan bahwa asap rokok dapat memicu pelepasan IL-8, IL-6, dan TNF- $\alpha(3,4)$.

Hasil dari beberapa penelitian lainnya menunjukkan bahwa Acute Effect of Cigarette Smoke (ACS) mengakibatkan efek supresif terhadap eosinofil dan beberapa sitokin proinflamasi akibat pengaruh yang ditimbulkan oleh karbon monoksida (CO) baik yang secara langsung berasal dari asap rokok maupun yang diproduksi oleh heme oxigenase-1 (HO-1) dalam sel paru-paru yang mengalami inflamasi $(5,6)$.

Upaya pengendalian inflamasi dapat dilakukan dengan penggunaan senyawa polifenol. Hasil penelitian menunjukkan bahwa polifenol berfungsi untuk meningkatkan status antioksidan dan respon imunitas. Kandungan karotenoid pada daun ubi jalar ungu (purple sweet potato leaves=PSPL) juga dapat meningkatkan aktivitas immunomodulator (7-10). Daun ubi jalar ungu (PSPL) merupakan tanaman yang mudah tumbuh di daerah tropis, termasuk di Indonesia. Daun ini mengandung polifenol, flavonoid, dan karotenoid yang paling tinggi diantara sayur-sayuran lainnya, sehingga memiliki kemampuan menangkap radikal bebas. Oleh karena itu perlu dilakukan penelitian lebih lanjut untuk mengetahui pengaruh pemberian PSPL yang memiliki kandungan antioksidan tinggi terhadap marker inflamasi TNF- $\alpha$, IL-6, dan NF-KB pada tikus yang dipapar asap rokok.

\section{METODE}

\section{Subjek Penelitian}

Penelitian ini adalah penelitian eksperimental dengan rancangan penelitian Post test Only Randomized Control Group Design menggunakan hewan coba tikus wistar jantan usia 6-8 minggu dengan berat badan awal 140-250 gram, warna bulu putih dan tikus aktif. Penentuan kelompok perlakuan dan control dilakukan dengan metode simple random sampling.

\section{Prosedur Penelitian}

Subjek penelitian terbagi menjadi 5 kelompok perlakuan. Pertama, kelompok yang diberikan diet normal dan tidak dipapar asap rokok $(\mathrm{K}+)$. Kedua, kelompok yang diberikan diet normal dan dipapar asap rokok (K-). Ketiga, kelompok yang diberikan diet normal, dipapar asap rokok dan diberikan tepung PSPL 0,07g selama 30 hari (P1). Keempat, kelompok yang diberikan diet normal, dipapar asap rokok dan diberikan tepung PSPL 0,14 g (P2), dan kelima, kelompok yang diberikan diet normal, dipapar asap rokok dan diberikan tepung PSPL 0,28 g (P3).

Sebelum PSPL diberikan kepada kelompok perlakuan, dilakukan proses penepungan terlebih dahulu agar mempermudah perhitungan takaran pemberian dan intervensinya. Setelah dilakukan proses penepungan kemudian PSPL dianalisis kadar polifenolnya. Hasil pengukuran kadar polifenol yang dilakukan pada setiap100 gram tepung PSPL menunjukkan kandungan PSPL sebesar 1805mg GEA.

Pada tahap awal percobaan seluruh tikus diadaptasikan pada kondisi laboratorium selama 7 hari di laboratorium Farmakologi Fakultas Kedokteran, Universitas Brawijaya Malang. Selanjutnya seluruh tikus ditimbang berat badannya dan dikelompokkan berdasarkan perlakuannya. Paparan asap rokok pada tikus dilakukan dengan menggunakan asap rokok kretek yang dihasilkan melalui bantuan alat smoking pump. Dosis paparan asap rokok setiap ekor tikus adalah asap rokok yang dihasilkan dari satu batang rokok yang dihabiskan selama 5 menit, dan diberikan selama 30 hari secara berkelanjutan. Tepung PSPL diberikan kepada tikus kelompok P1, P2 dan P3 melalui sonde selama 30 hari.

\section{Uji Biokimia}

Pengukuran kadar TNF- $\alpha$, IL-6, dan NF-kB dilakukan dengan metode ELISA, dengan menggunakan ELISA kit merk Komabiotek. Pembacaan nilai absorbansi dilakukan pada panjang gelombang $492 \mathrm{~nm}$ untuk kadar TNF- $\alpha$ dan IL-6 serta pada panjang gelombang $450 \mathrm{~nm}$ untuk kadar NF-KB.

\section{Analisis Statistik}

Analisis data TNF- $\alpha$ dan NF-KB menggunakan One Way ANOVA, yang kemudian dilanjutkan dengan post hoc Tukey untuk mengetahui kelompok mana yang berbeda. Analisis data IL-6 menggunakan Kruskal Wallis yang kemudian dilanjutkan dengan uji Man Whitney untuk mengetahui kelompok mana yang berbeda, dengan nilai $\mathrm{P}<0,05$.

\section{HASIL}

Hasil penelitian menunjukkan pemberian PSPL pada tiga dosis menunjukkan perbedaan TNF- $\alpha$, IL-6, dan NF-KB dibandingkan kelompok kontrol negatif dan positif.

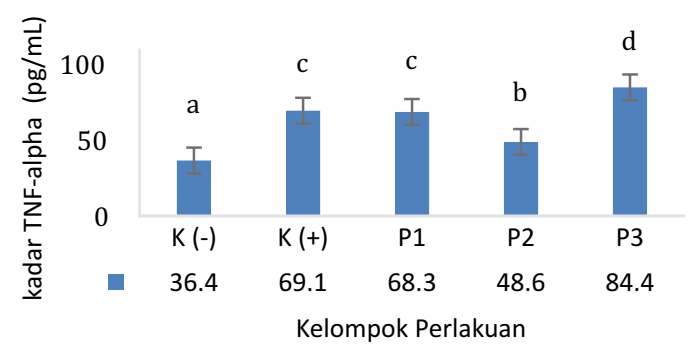

Gambar 1. Rerata kadar TNF- $\alpha$

Berdasarkan Gambar 1 rerata kadar TNF- $\alpha$ terendah ada pada kelompok K(-) yaitu sebesar $36,4 \mathrm{pg} / \mathrm{ml}$, sedangkan kadar TNF- $\alpha$ tertinggi yaitu pada kelompok P3 yaitu sebesar $84,4 \mathrm{pg} / \mathrm{ml}$. Jika dilihat dari kelompok perlakuan, pada kelompok P2 menunjukkan kadar TNF- $\alpha$ terendah dibandingkan kelompok perlakuan lainnya (P1,P2) yaitu sebesar $68,3 \mathrm{pg} / \mathrm{ml}$. Hasil uji statistik One Way ANOVA $(\alpha=0,05)$ menunjukkan ada perbedaan kadar TNF- $\alpha$ yang signifikan antar kelompok $(p=0,001)$. Hasil uji lanjut dengan uji post hoc Tukey menunjukkan kelompok K(-) dan 
P2 memiliki kadar TNF- $\alpha$ yang berbeda dengan semua kelompok perlakuan. Demikian pula kelompok K(-) berbeda dengan P2. Dilihat dari trend kadar TNF- $\alpha$ menunjukkan bahwa terjadi penurunan kadar hingga kelompok P2 akan tetapi terjadi peningkatan kadar pada kelompok P3, bahkan melebihi dari kelompok $\mathrm{K}(+)$. Hasil penelitian ini menunjukkan bahwa pemberian PSPL pada dosis $0,07 \mathrm{~g}$ dan $0,14 \mathrm{~g}$ mampu memberikan efek kadar TNF- $\alpha$ yang lebih rendah pada tikus dengan paparan asap rokok, namun pada dosis $0,28 \mathrm{~g}$ justru memberikan kadar TNF- $\alpha$ yang lebih tinggi dibandingkan kondisi paparan asap rokok

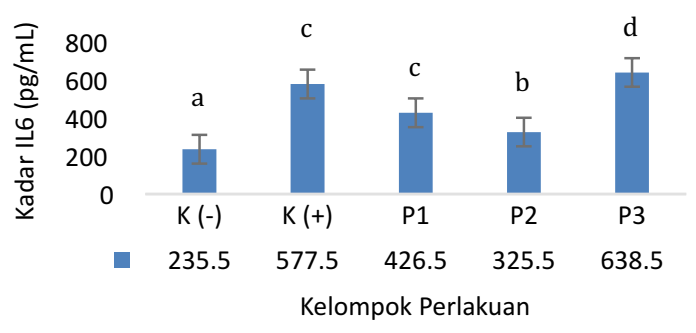

Gambar 2. Rerata kadar IL-6

Hasil pada Gambar 2 menunjukkan bahwa rerata kadar IL6 terendah pada kelompok K(-) yaitu sebesar $235,5 \mathrm{pg} / \mathrm{mL}$. Rerata kadar IL-6 tertinggi adalah sebesar $638,5 \mathrm{pg} / \mathrm{mL}$ terdapat pada kelompok P3. Jika dilihat berdasarkan kelompok perlakuan, maka kelompok P2 memiliki kadar IL-6 terendah dibandingkan yang lain (P1, P2) yaitu sebesar $325,5 \mathrm{pg} / \mathrm{ml}$. Hasil uji statistic Kruskal Wallis $(\alpha=0,05)$ menunjukkan ada perbedaan kadar IL-6 yang signifikan antar kelompok $(p=0,015)$. Hasil uji lanjut dengan Man Whitney menunjukkan kelompok K(-) berbeda dengan semua kelompok $\mathrm{K}(+), \mathrm{P} 1, \mathrm{P} 2$, dan $\mathrm{P} 3)$, sedangkan kelompok $\mathrm{K}(+)$ berbeda dengan kelompok $\mathrm{K}(-)$ dan P2. Kadar IL-6 kelompok P2 berbeda dengan semua kelompok perlakuan. Trend data menunjukkan terjadi penurunan kadar IL-6 hingga pada pemberian PSPL dosis $0,14 \mathrm{~g}$ kemudian terjadi kenaikan pada dosis $0,28 \mathrm{~g}$. Kadar IL-6 pada kelompok P3 (PSPL 0,28 g) lebih tinggi dibandingkan pada kelompok $\mathrm{K}(+)$.

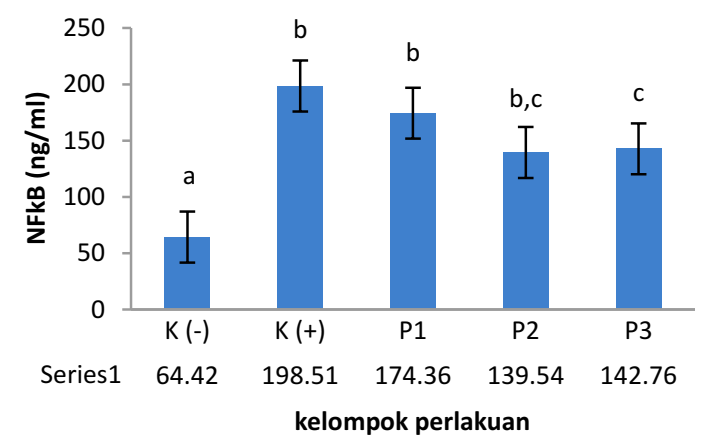

Gambar 3. Rerata kadar NFkB

Berdasarkan Gambar 3 rerata kadar NFkB terendah pada kelompok kontrol negatif yaitu sebesar $64,42 \mathrm{ng} / \mathrm{ml}$. Kadar NFkB tertinggi yaitu pada kelompok kontrol positif yaitu sebesar 198,51ng/ml. Jika dilihat pada kelompok yang diberikan PSPL terlihat bahwa kadar NFkB pada kelompok P2 memiliki rerata kadar NFkB yang terendah dibandingkan kelompok lain. Hasil uji statistik One Way ANOVA $(\alpha=0,05)$ menunjukkan ada perbedaan kadar NFkB yang signifikan antar kelompok $(p=0,001)$. Hasil uji lanjut dengan post Hoc Tukey menunjukkan kelompok K(-) berbeda dengan semua kelompok perlakuan. Kelompok $\mathrm{K}(+)$ berbeda dengan kelompok P1 dan P2, sedangkan kelompok P2 tidak berbeda dengan kelompok $\mathrm{K}(+), \mathrm{P} 1$ maupun P3. Secara keseluruhan data menunjukkan bahwa terjadi penurunan kadar NFkB hingga pada kelompok P2 (PSPL 0,14 g), akan tetapi meningkat pada kelompok P3 $(0,28 \mathrm{~g})$.

\section{DISKUSI}

Asap rokok memproduksi sejumlah besar Reactive Oxygenated Species (ROS). ROS mengaktivasi signal intraseluler pada sel endotel yang memicu aktivasi gendan pembentukan mediator inflamasi yang mengakibatkan inflamasi (4).

TNF- $\alpha$ merupakan salah satu sitokin pro inflamasi. Hasil penelitian sebelumnya menunjukkan bahwa TNF- $\alpha$ merupakan sitokin utama yang menyebabkan inflamasi akut dan berperan penting terhadap perkembangan patogenesis COPD akibat rokok (11). Hasil penelitian ini juga menunjukkan bahwa rerata kadar TNF- $\alpha$ pada kelompok kontrol positif (kelompok yang terpapar asap rokok) lebih tinggi jika dibandingkan dengan kelompok kontrol negatif (kelompok yang tidak terpapar asap rokok). Asap rokok dapat mengaktivasi makrofag dan menginduksi pelepasan TNF- $\alpha$ melalui jalur ERK1/2, sehingga pemaparan asap rokok akan meningkatkan kadar TNF- $\alpha$ (12). ERK atau disebut juga classic MAPK merupakan molekul yang memediasi pembentukan protease dan sitokin apabila mendapatkan rangsangan, dimana asap rokok merupakan salah satu stimulan yang dapat memediasi aktivasi classic MAPK dan menyebabkan inflamasi.

Hasil lain pada penelitian ini menunjukkan bahwa pemberian PSPL pada dosis 0,07 dan $0,14 \mathrm{~g}$ memberikan penurunan rerata kadar TNF- $\alpha$ jika dibandingkan kontrol positif dan mendekati rerata kadar TNF- $\alpha$ pada kontrol negatif. PSPL dengan kandungan polifenol bekerja menurunkan ekspresi ERK1, ERK 2 dan p38MAPK dengan akibat terjadi penghambat sekresi TNF- $\alpha(13,14)$.

Sitokin proinflamasi lainnya yang mengalami peningkatan akibat asap rokok adalah IL-6. Hasil penelitian ini menunjukkan bahwa kelompok yang terpapar asap rokok memiliki rerata kadar IL-6 lebih tinggi dibandingkan dengan kontrol negatif. Hal ini sesuai dengan hasil penelitian sebelumnya menunjukkan bahwa asap rokok dapat meningkatkan sitokin pro inflamasi seperti IL-6 $(5,15)$. Terjadinya peningkatan kadar IL-6 diakibatkan oleh tingginya kadar TNF- $\alpha$. Peningkatan TNF- $\alpha$ dapat meningkatkan produksi IL-6 melalui jalur FAK/P13K/Akt dan NF-KB pada sel mioblas (16).

Penelitian ini menunjukkan bahwa terjadi penurunan IL-6 pada perlakuan tikus yang terpapar asap rokok dengan PSPL dosis 0,07 g dan 0,14 g jika dibandingkan dengan kelompok yang hanya terpapar asap rokok. Kandungan polifenol PSPL dapat menurunkan dan menghambat sintesis IL-6 $(17,18)$. Penurunan dan penghambatan IL-6 oleh polifenol melalui penurunan P38 dan PKC- $\theta(5,16)$. 
Hasil yang cukup menarik adalah ditemukannya penyimpangan pada kelompok yang terpapar asap rokok dan mendapatkan tepung PSPL dosis tertinggi $(0,28 \mathrm{~g})$ yang mengalami peningkatan kadar TNF- $\alpha$, IL- 6 dan NFKB. Hal ini menunjukkan kemungkinan bahwa pada dosis yang tinggi polifenol memiliki efek pro oksidan. Hal ini dibuktikan dengan beberapa penelitian lain yang menunjukkan bahwa polifenol akan memberikan efek pro oksidan pada dosis tinggi atau jika berikatan dengan ion logam seperti besi. Tetapi besarnya dosis yang dikatakan cukup tinggi pada penggunaan polifenol yang dapat menyebabkan aktivasi pro oksidan belum dapat dipastikan dan pada penelitian ini membuktikan dosis tertinggi PSPL $(0,028 \mathrm{~g})$ mengakibatkan efek tersebut muncul. Penelitian lain menyatakan bahwa jika terdapat ion logam yang tidak terserap pada saluran cerna, maka ion logam tersebut dapat berikatan dengan polifenol dan mengubah perannya menjadi prooksidan $(19,20)$. Pada penelitian ini tidak dilakukan proses peniadaan kandungan logam pada bahan makanan yang diberikan. $\mathrm{Hal}$ ini merupakan penjelasan lain mengapa terdapat perbedaan profil TNF- dan IL-6 pada kelompok perlakuan terpapar asap rokok dan mendapatkan tepung PSPL dosis $0,28 \mathrm{~g}$.

Molekul lain yang berperan terhadap inflamasi dan diaktivasi oleh asap rokok adalah NF-KB, STAT, dan AP-1

\section{DAFTAR PUSTAKA}

1. Obradović LN, Pešut D, Trifunović VS, and Adžić T. Influence of Tobacco Smoke on the Appearance of Oxidative Stress in Patients with Lung Cancer and Chronic Obstructive Pulmonary Diseases. Vojnosanitetski Pregled. 2006; 63(10): 893-895.

2. Mannino DM and Buist AS. Global Burden of COPD: Risk Factors, Prevalence, and Future Trends. The Lancet. 2007; 370(9589): 765-773.

3. Kode A, Yang SR, and Rahman I. Differential Effects of Cigarette Smoke on Oxidative Stress and Proinflammatory Cytokine Release in Primary Human Airway Epithelial Cells and in a Variety of Transformed Alveolar Epithelial Cells. Respiratory Research. 2006; 7(1): 132.

4. Lee J, Taneja V, and Vassallo R. Cigarette Smoking and Inflammation: Cellular and Molecular Mechanisms. Journal of Dental Research. 2012; 91(2):142-149.

5. Chang WH, Hu SP, Huang YF, Yeh TS, and Liu JF. Effect of Purple Sweet Potato Leaves Consumtion on Excercise-Induced Oxidative Stress and $I L-6$ and HSP72 Levels. The Journal of Applied Physiology. 2010; 109(6): 1710-1715.

6. Chang WH, Chen CM, Hu SP, Kan NW, Chiu CC, and Liu JF. Effect of Purple Sweet Potato Leaf Consumtion on the Modulation of the Antioxidative Status in Basketball Players during Training. Asia Pacific Journal of Clinical Nutrition. 2007; 16(3): 455-461.

7. Chang WH, Chen CM, Hu SP, Kan NW, Chiu CC, and Liu JF. Effect of Purple Sweet Potato Leaves Consumtion on the Modulation of the Immune Respone in Basketball Players during Training Period. Asia Pacific Journal of Clinical Nutrition. 2007; 16(4): 609-615.

8. Chen CM, Li SC, Lin YL, Hsu CY, Shieh MJ, and Liu JF.
$(4,14)$. Hasil penelitian ini menujukkan bahwa profil NF-KB tertinggi dimiliki oleh kelompok kontrol positif, sejalan dengan profil TNF- $\alpha$ dan IL-6. Jalur NF-KB yang berhubungan terutama dengan profil TNF- dikenal sebagai jalur kanonik (21) Jumlah TNF- $\alpha$ bersama dengan IL-1 atau LPS melakukan komunikasi melalui sejenis signal adapter dalam proses aktivitas IKK. Komunikasi ini akan menyebabkan pelepasan NF-kB dimmer dalam upaya untuk mengarahkan pada target sel, kemudian akan dilakukan pelepasan elemen spesifik $\mathrm{kB}$.

Pada kondisi TNF- $\alpha$ mengalami koreksi malalui keterlibatan polifenol maka terjadi penekanan jumlah NFKB yang akan dihasilkan. Terbukti pada penelitian kadar NF-KB pada kelompok perlakuan terpapar asap rokok dan mendapatkan tepung PSPL dosis 0,07g dan terpapar asap rokok dan mendapatkan tepung PSPL dosis $0,14 \mathrm{~g}$ mengalami penurunan dibandingkan kontrol positif. Hal ini memperkuat teori bahwa TNF- $\alpha$ yang terkoreksi akan mempengaruhi hasil NF-KB (21).

Dari penelitian ini dapat disimpulkan bahwa tepung PSPL dengan dosis $0,14 \mathrm{~g}$ dapat menurunkan produksi sitokin pro inflamasi TNF- $\alpha$, IL-6 dan NF-KB.I Untuk memperoleh konsistensi hasil dan penentuan dosis yang dapat menurunkan sitokin proinflamasi dan aman, maka perlu dilakukan penelitian lebih lanjut dengan menggunakan variasi dosis lainnya.

Consumption of Purple Sweet Potato Leaves Modulated Human Immune Respone: T-Lymphocytes Fungstion, Litic Activity of Natural Killer and Antibody Production. The World Journal of Gastroenterology. 2005; 11(37): 5777-5781.

9. Churg A, Dai J, Tai H, Xie C, and Wright JL. Tumor Necrosis Factor-alpha is Central to Acute Cigarette Smoke-induced Inflammation and Connective Tissue Breakdown. American Journal of Respiratory and Critical Care Medicine. 2002; 166(6): 849-854.

10. Demirjian L, Abboud RT, Li H, and Duronio V. Acute Effect of Cigarette Smoke on TNF-A Release by Macrophages Mediated through the ERK1/2 Pathway. Biochimica et Biophysica Acta. 2006; 1762(6): 592597.

11. Chao PY, Huang YP, and Hsieh WB. Inhibitive Effect of Purple Sweet Potato Leaf Extract and Its Components on Cell Adhesion and Inflammatory Response in Human Aortic Endothelial Cells. Cell Adhesion \& Migration. 2013; 7(2): 237-245.

12. Wang Y, Zheng Y, Lu J, et al. Purple Sweet Potato Color Suppresses Lipopolysaccharide-Induced Acute Inflammatory Response in Mouse Brain. Neurochemistry International. 2010; 56(3): 424-430.

13. Kuschner WG, D'Alessandro A, Wong $H$, and Blanc PD. Dose-Dependent Cigarette Smoking-Related Inflammatory Responses in Healthy Adults. European Respiratory Journal. 1996; 9(10): 1989-1994.

14. Jeong SH, Park JH, Kim JN, et al. Up-Regulation of TNFAlpha Secretion by Cigarette Smoke is Mediated by Egr-1 in Hacat Human Keratinocytes. Experimental Dermatology. 2010; 19(8): e206-e212.

15. Tseng WP, Su CM, and Tang CH. FAK Activation is Required for TNF-Alpha-Induced IL-6 Production in 
Myoblasts. Journal of Cellular Physiology. 2010; 223(2): 389-396.

16. Santangelo $C$, Varì $R$, Scazzocchio $B$, Di Benedetto R, Filesi C, and Masella R. Polyphenols, Intracellular Signalling and Inflammation. Annali dell'Istituto Superiore di Sanità. 2007; (43)4: 394-405.

17. Yordi EG, Pérez EM, Matos MJ, and Villares EU. Antioxidant and Pro-Oxidant Effects of Polyphenolic Compounds and Structure-Activity Relationship Evidence. In: Bouayed J and Bohn T. Nutrition, WellBeing and Health. Croatia: INTECH; 2012; p. 23-41.

18. Halliwell B. Are Polyphenols Antioxidants or ProOxidants? What do We Learn from Cell Culture and In
Vivo Studies? Archives of Biochemistry and Biophysics. 2008; 476(2): 107-112.

19. Kubo S, Kobayashi M, Masunaga Y, et al. Cytokine and Chemokine Expression in Cigarette Smoke-Induced Lung Injury in Guinea Pigs. European Respiratory Journal. 2005; 26(6): 993-1001.

20. Barnes PJ. The Cytokine Network in Chronic Obstructive Pulmonary Disease. American Journal of Respiratory Cell and Molecular Biology. 2009; 41(6): 631-638

21. Oeckinghaus $A$ and Ghosh S. The NF-KB Family of Transcription Factor and its Regulation. Cold Spring Harbor Perspectives in Biology. 2009; 1(4); a000034. 